\title{
1. Introduction: Courts, privacy and data protection in the digital environment
}

\section{Evangelia Psychogiopoulou and Maja Brkan}

Digital technologies have raised key questions about the role of courts in digital policies and regulation from a fundamental rights perspective. Over the past few years European courts and national courts in several Member States of the European Union (EU) have been called upon to consider a number of cases relating to technological advances. In interpreting and applying existing laws they have ruled on disputes concerning new technologies with important fundamental rights implications. In several instances national courts have sought to safeguard fundamental rights by reviewing interference with them in the pursuit of public interests such as national security or the prevention of disorder or crime. On other occasions they have engaged in a balancing exercise to reconcile distinct fundamental rights that are seemingly at odds in the digital setting. The European Court of Human Rights (ECtHR) and the Court of Justice of the European Union (CJEU) have also issued rulings in this regard, delivering authoritative pronouncements on fundamental rights and their protection in the digital era.

As is common knowledge, the ECtHR rules on both individual and state applications alleging breach of the European Convention on Human Rights (ECHR). Individuals may thus seek redress before it for the violation of rights that are safeguarded by the ECHR. The ECHR (adopted in 1950) is a 'living instrument' according to the ECtHR, which 'must be interpreted in the light of present-day conditions'.${ }^{1}$ This means with due account of developments in social and legal circumstances, technological and scientific changes. In a number of recent cases that have been brought before it, the ECtHR has breathed new life into the

1 Tyrer $v$ the UK App no 5856/72 (ECHR, 25 April 1978), para. 31. 
provisions of the ECHR, testifying to its interaction with technological innovations.

The CJEU has also adjudicated cases related to the development of new technologies. In many cases when interpreting or examining the validity of EU law, it has investigated the compliance of relevant contested measures with fundamental rights. In addition, through the interpretation of EU law provisions the CJEU has also indirectly judged on the compatibility with these provisions of national legislation implementing EU law. Rulings have increasingly drawn on the Charter of Fundamental Rights of the European Union (Charter or CFR), making clear that besides the ECtHR, the CJEU has a key role to play for the upholding of fundamental rights in the digital era.

Judicial review at the national and supranational level has gone hand in hand with the proliferation of cases concerning privacy and the protection of personal data. Technological change has raised a number of questions about privacy, casting doubt on the adequacy of existing laws and policies. The internet in particular, and the ease it offers in terms of disseminating and receiving information, has posed enormous challenges to privacy legislation. Technological developments have further profoundly transformed the way in which personal data are collected, processed, used and shared by both public and private actors, revealing that established legal frameworks might have to be reconsidered. Disputes have not taken long to reach the courts and, significantly, they have been endowed with an important fundamental rights component. National constitutions, and constitutional and higher courts have provided the primary normative and judicial framework for legal action aimed at guaranteeing privacy and data protection rights. Moreover, the ECHR and the Charter have enriched the arsenal of privacy and data protection rights available to litigants, with the ECtHR and the CJEU becoming increasingly targeted for the adjudication of privacy and data protection disputes.

The idea for the edited volume Courts, Privacy and Data Protection in the Digital Environment was born at one of the many conferences that have been taking place over the past years on privacy and data protection. These topics were covered extensively from various angles, but not from the perspective of judicial approaches towards these two fundamental rights. Of course new technologies, the challenges they create for the formulation of national and European digital policies that comply with fundamental rights, and the impact of national and supranational policymaking processes on the protection of privacy and data protection rights 
have thus far been afforded significant attention in the literature, becoming the object of meticulous analysis. ${ }^{2}$ However, there has been less debate on the contribution of European and national courts to the shaping of national constitutional orders concerning privacy and data protection, and the role and ability of courts more broadly to safeguard privacy and data protection in the new digital world. ${ }^{3}$ This is a glaring gap in legal and European studies scholarship that this book seeks to fill.

2 Christopher Kuner, European Data Protection Law: Corporate Compliance and Regulation (OUP 2007); Ronald Leenes, Bert-Jaap Koops and Paul de Hert Constitutional Rights and New Technologies: A Comparative Study (TMC Asser Press 2008); Viktor Mayer-Schönberger, Delete: The Virtue of Forgetting in the Digital Age (Princeton University Press 2009); Serge Gutwirth, Yves Poullet, Paul de Hert and Ronald Leenes (eds), Computers, Privacy and Data Protection: An Element of Choice (Springer 2011); Theodore Konstadinides, 'Destroying Democracy on the Ground of Defending it? The Data Retention Directive, the Surveillance State and our Constitutional Ecosystem' (2011) European Law Review 36(5), 722; Paul de Hert and Dariusz Kloza, 'Internet (Access) as a New Fundamental Right: Inflating the Current Rights Framework?' (2012) European Journal of Law and Technology 3, available at <http://ejlt.org/ article/view/123/268> accessed 12 April 2016; Orla Lynskey, 'From Marketmaking Tool to Fundamental Right: The Role of the Court of Justice in Data Protection's Identity Crisis' (2013), in Serge Gutwirth, Ronald Leenes, Paul de Hert and Yves Poullet (eds), European Data Protection: Coming of Age (Springer 2012), 59-84; Gloria González Fuster, The Emergence of Personal Data Protection as a Fundamental Right of the EU (Springer 2014); Hielke Hijmans and Herke Kranenborg (eds), Data Protection Anno 2014: How to Restore Trust? Contributions in Honour of Peter Hustinx, European Data Protection Supervisor (2004-2014) (Intersentia 2014); Giovanni Sartor, 'Providers' Liabilities and the Right to Be Forgotten' (2013) EUI Working Papers, RSCAS 2013/37, available at <http://cadmus.eui.eu/bitstream/handle/1814/ 27215/RSCAS_2013_37.pdf?sequence=1\&isAllowed=y $>$ accessed 12 April 2016; Federico Ferretti, 'Data Protection and the Legitimate Interest of Data Controllers: Much Ado about Nothing or the Winter of Rights?' (2014) Common Market Law Review 51(3), 843-868; David Erdos, 'From the Scylla of Restriction to the Charybdis of Licence? Exploring the Scope of the "Special Purposes" Freedom of Expression Shield in European Data Protection' (2015) Common Market Law Review 52(1), 119-153.

3 See, for example, Paul De Hert and Serge Gutwirth, 'Data Protection in the Case Law of Strasbourg and Luxemburg: Constitutionalisation in Action', in Serge Gutwirth et al. (eds), Reinventing Data Protection? (Springer 2009) 3; Eleni Kosta, 'The Way to Luxembourg: National Court Decisions on the Compatibility of the Data Retention Directive with the Rights to Privacy and Data Protection' (2013) SCRIPTed 10(3), 339-363; Gordon Nardell QC, 'Levelling up: Data Privacy and the European Court of Human Rights', in Serge Gutwirth et al. (eds), Data Protection in a Profiled World (Springer 2010) 43-52. 
The aim of this edited volume is accordingly to examine the jurisprudence of European and national courts on privacy and data protection and to investigate the contribution of European and national judiciaries to the development of legal standards and policies that strike an appropriate balance between privacy and data protection and on the other hand other fundamental rights and interests in a rapidly changing technological environment. Are national and European courts confronted with cases that are based on allegations of a breach of the rights to privacy and data protection? What are the sources of protection of these rights and how are they framed in terms of the nature and scope of protection that is accorded to them? How do national courts balance the rights to privacy and data protection with other fundamental rights and interests? What is the influence of the jurisprudence of the ECtHR and of the CJEU on the process and in what ways have the two European courts dealt with privacy and data protection issues? Furthermore, does resort to national and European courts take place with a clear focus on law and policy reform in support of strengthened protection offered to privacy and data protection or on the contrary to other conflicting rights and interests? Finally, what is the impact of European and national court decisions on national laws and policies? These are the central research questions that this book sets out to address.

Evidently, this volume explores judicial attitudes to privacy and data protection in the context of the European multi-level system of rights protection. Three systems of sources of norms and their judicial arms are discussed: national constitutional norms which are commonly applied and enforced by national constitutional and/or supreme courts, the Charter which is to be upheld by the CJEU but also by national courts in areas that fall within the scope of EU law, and the ECHR, respect for whose provisions is to be ensured by the ECtHR and national courts through the incorporation of the ECHR at the national level. Moreover, the fundamental rights protected by the ECHR constitute general principles of EU law, which brings the two layers of fundamental rights protection - the EU and the ECHR - into alignment, at least to a certain degree. This multi-level structure, which is to become even more interconnected and integrated with the accession of the EU to the ECHR ${ }^{4}$ - a project that has been brought to a standstill by the $\mathrm{CJEU}^{5}$ - renders

\footnotetext{
4 See Article 6(2) Treaty on European Union.

5 See CJEU, Opinion 2/13 [2014] ECLI:EU:C:2014:2454; Bruno de Witte and Šejla Imamović, 'Opinion 2/13 on Accession to the ECHR: Defending the EU Legal Order Against a Foreign Human Rights Court' (2015) European Law Review 40(5), 683.
} 
the study of national and European jurisprudence on the rights to privacy and personal data protection particularly intriguing. This is because each system of norms and judicial branches comes with its own features and characteristics. Consequently, judicial approaches to privacy and data protection may converge but also vary significantly and sometimes even are in contrast to each other. This signals the importance of the rights-related legal norm chosen and invoked, and of the judicial arena selected for the contestation of rules, policies and practices that jeopardize the protection of privacy and personal data.

The attractiveness that courts may or may not have for the issuing of privacy and data protection decisions with a fundamental rights dimension is a key factor conditioning the extent and ways in which individuals and groups become motivated to seek legal redress. This is also the case as regards the extent and ways in which individuals and groups use the law to pursue broader objectives concerned with law and policy reform in support of increased (or conversely, decreased) protection of privacy and personal data rights. Generally speaking, claiming and enforcing rights through courts can prove a precious tool for social mobilization, ${ }^{6}$ contributing to broader strategies devised for the modification of laws and policies (such as advocacy campaigns, media campaigns or lobbying the government). Litigation related to fundamental rights has indeed progressively been used as a means to exert pressure for reform, ${ }^{7}$ bolstering the power of courts to steer policy-making and influence the design of laws and regulations. This is because in the course of applying

6 See in particular Rachael Cichowski, The European Court and Civil Society: Litigation, Mobilization and Governance (Cambridge University Press 2007); Michael W. McCann, Rights at Work. Pay Equity Reform and the Politics of Legal Mobilization (University of Chicago Press 1994); David A. Schultz (ed), Leveraging the Law: Using the Courts to Achieve Social Change (Peter Lang 1998).

7 Karen J. Alter and Jeannette Vargas, 'Explaining Variation in the Use of European Litigation Strategies' (2000) Comparative Political Studies 33(4), 452; Dia Anagnostou and Susan Millns, 'Gender Equality, Legal Mobilisation and Feminism in the European Multi-Level System' (2013) Canadian Journal of Law and Society 28, 1; Lisa Conant, 'Individuals, Courts and the Development of European Social Rights' (2006) Comparative Political Studies 39, 76; Evangelia Psychogiopoulou, 'European Courts and the Rights of Migrants and Asylum Seekers in Greece', in Dia Anagnostou (ed), Rights and Courts in Pursuit of Social Change. Legal Mobilisation in the Multi-Level European System (Hart Publishing 2014) 129; Lisa Vanhala, 'Anti-discrimination Policy Actors and their Use of Litigation Strategies: The Influence of Identity Politics' (2009) Journal of European Public Policy 16, 738. 
and interpreting legal norms, judges can promote or, by contrast, undermine the application of given rules, including those of constitutional value, and in consequence, support or resist specific policy decisions embedded in legislation, which may lead to corroborating and even stimulating law and policy change. Notably, the use of law and resort to courts in the pursuit of such wider objectives of law and policy reform may take place at different levels given the existence of national judicial mechanisms, as well as an array of supranational institutions and structures to which European states belong. In this context, the ECtHR and the CJEU have attracted much interest as platforms of support for organized interests and individuals who seek to affect the law and public policies by asserting their rights.

Against this background, through the examination of national and European jurisprudence on privacy and data protection, this book simultaneously explores litigation patterns before national and European courts. In particular it discusses the type of rights claims brought before the judiciary and it identifies those cases that could be considered as instances of 'strategic' litigation. Strategic litigation is understood to be litigation that is primarily concerned with law and policy reform, based on the selection of cases that allow litigants to penetrate deeper into and address wider societal problems. Strategic litigation hence surpasses the litigant's individual interest. Moreover, as aptly observed in the literature, 'besides seeking to challenge existing laws and policies, strategic litigation can have less ambitious but equally important goals such as to clarify laws, to promote human rights consciousness and public attitude change ... [or] to document injustices' ${ }^{8}$ In the field of privacy and data protection, strategic litigation may be instigated by an individual, by an individual on behalf of a group (representative action), a group of individuals (collective action) and public authorities (mostly data protection authorities) as well as supranational bodies such as the EU institutions. In such instances, the intention of litigants can very well go beyond merely winning the case, encompassing broader objectives of law and policy change. It is worth noting, however, that while strategic litigation can take place in pursuit of reformist goals for strengthened protection of privacy and personal data rights, fundamental rights can also be tactically invoked before courts to challenge and contest increased protection given to privacy and personal data safeguards.

8 Dia Anagnostou, 'Law and Rights' Claiming on behalf of Minorities in the Multi-level European System', in Dia Anagnostou (ed), Rights and Courts in Pursuit of Social Change. Legal Mobilisation in the Multi-Level European System (Hart Publishing 2014) 1, 4. 
More concretely, the analysis in this book is structured as follows: not including the introduction, the book is composed of 11 chapters, of which two chapters examine the jurisprudence of the CJEU and the ECtHR in the field of privacy and data protection. The following nine chapters shift attention to national privacy and data protection case law. The aim is not to offer an exhaustive analysis of the case law, but to identify key trends and patterns in national and European judicial reasoning as regards the rights to privacy and data protection and their balancing with other fundamental rights and interests.

Chapter 2 by Maja Brkan highlights the difficulties the CJEU faces when deciding issues relating to privacy and data protection at the EU level. It stresses the need for clarity concerning the relationship between the fundamental right to privacy and the fundamental right to the protection of personal data and critically analyses the most relevant cases in this field such as Digital Rights Ireland, ${ }^{9}$ Google Spain, ${ }^{10}$ and Schrems. ${ }^{11}$ Chapter 3 by Evangelia Psychogiopoulou focuses on the jurisprudence of the ECtHR. It discusses a series of rulings pertaining to Article $8 \mathrm{ECHR}$ on the right to respect for private and family life, home and correspondence, which offers protection to both privacy and personal data, and assesses the stance of the ECtHR particularly as regards conflicts with free speech as well as interference for the purposes of protecting national security and preventing crime.

The analysis continues with the examination of national case law in nine European countries: Belgium, Finland, Germany, Greece, Italy, the Netherlands, Slovakia, Spain and the UK. The countries chosen include Western European countries, which have in principle established fundamental rights policies and institutions, and Eastern European countries whose transition to democratic rule has been associated with processes of strengthening human rights protection, promotion and consolidation. The countries selected also reflect the differences in constitutional traditions between Nordic countries where litigation is in general not embedded in societal issues, and Southern countries where litigation is societally more acceptable. They further depict diversity of legal orders (common law/ civil law) and expose the variety of the judicial systems reviewed, since not all of them have a constitutional court. In fact although the emphasis is generally placed on the jurisprudence of domestic constitutional and

\footnotetext{
9 Joined Cases C-293/12 and C-594/12 Digital Rights Ireland and Seitlinger and Others [2014] ECLI:EU:C:2014:238.

10 Case C-131/12 Google Spain and Google [2014] ECLI:EU:C:2014:317.

11 Case C-362/14 Schrems [2015] ECLI:EU:C:2015:650.
} 
supreme courts, in those countries without a constitutional court, attention is given, besides the jurisprudence of supreme courts, to rulings issued by lower courts when these raise fundamental rights issues and are therefore of constitutional importance. In addition, the group of countries studied reflects the impact that distinct processes of federalization and devolution within states may have on the protection of fundamental rights. It thus comprises a variety of legal and judicial structures at national and subnational level which distinctly shape the environment in which privacy and data protection rights are invoked, applied and enforced.

Each country chapter follows a similar structure. The first substantive section of each chapter provides a succinct overview of the national legal framework on the protection of privacy and personal data, underlining relevant constitutional provisions when available. The second substantive section of each chapter deals with domestic privacy and data protection jurisprudence, whereas the third substantive section examines the influence of European fundamental rights and of the judgments of the CJEU and the ECtHR on the decisions of national courts. Litigation patterns at the national level are explored at the end, and this is followed by concluding remarks.

Chapter 4 by Paul De Hert on privacy and data protection in Belgium shows a great deal of loyalty towards Europe from the Belgian Constitutional Court. In stark contrast stands the Court of Cassation, whose case law has prioritized prosecutorial and employers' interests to the detriment of privacy and data protection. Chapter 5 by Tuomas Ojanen discusses the lack of jurisprudence of Finnish courts in the field of privacy and data protection. This is not only due to the Nordic legal culture but also to several ex ante measures that prevent cases from actually coming before the courts. Not only do public authorities pay careful attention to respecting citizens' rights, but the data protection regime ascribes great importance to preventive methods of compliance with privacy and data protection requirements. Chapter 6 by Johannes Eichenhofer and Christoph Gusy focuses on the jurisprudence of the German courts. Much of the protection offered to privacy and personal data in Germany stems from the creation of jurisprudential rights, which confirms domestic judges' strong fundamental rights culture. This favours comprehensive protective standards, yet concurrently portrays an important degree of resistance towards European influences. Chapter 7 by Tania Kyriakou probes the jurisprudence of the Greek courts. It explains that although the legal framework is well equipped and fully aligned to European standards, its judicial application is characterized by severe inconsistencies, especially on the part of higher courts such as the Court of Cassation. 
Chapter 8 by Claudio Di Cocco and Giovanni Sartor demonstrates the importance of the Italian jurisprudence for the evolution of privacy and data protection law and policy in Italy. Despite initial hesitation, domestic courts have gradually developed fully-fledged rights to privacy and personal data, determining their content and limits. Chapter 9 by Colette Cuijpers reveals the importance of balancing different rights and interests in Dutch jurisprudence. National courts exhibit no particular preference as regards the calibration of privacy and data protection rights with other fundamental rights and interests and act in line with the case law of the CJEU and the ECtHR. Chapter 10 by Martin Husovec observes that the Communist legacy has led to very strong safeguards in the field of privacy and data protection in Slovakia. Interestingly, despite a vibrant privacy-related jurisprudence in general, the Constitutional Court has developed its most significant privacy and data protection case law in the framework of the digital environment, in particular with regard to data retention and digital evidence. Chapter 11 by Gloria González Fuster is devoted to Spanish case law. The Spanish Constitutional Court has read in the Spanish Constitution an autonomous fundamental right to the protection of personal data. This has paved the way for strengthened dialogue of the Spanish courts with the CJEU, setting the scene for the delivery of seminal CJEU judgments. Chapter 12 by Orla Lynskey illustrates how the ECHR and the Charter have influenced the privacy and data protection jurisprudence of the UK courts. In the absence of a constitutional source of fundamental rights in the UK, the ECHR and the Charter have on the one hand facilitated the development of a new tort of 'misuse of personal information' in support of the protection of privacy and, on the other hand, have encouraged the application of a right to data protection in relevant disputes. 